\title{
Determination of Methylenomycin A Synthesis by the pSV1 Plasmid from Streptomyces violaceus-ruber SANK 95570
}

\author{
By ALFREDO AGUILAR† AND DAVID A. HOPWOOD* \\ John Innes Institute, Colney Lane, Norwich NR4 7UH, U.K.
}

(Received 25 January 1982)

\begin{abstract}
A plasmid (pSV1) of $110 \times 10^{6}$ daltons from a methylenomycin A producing strain of Streptomyces violaceus-ruber was detected on and isolated from agarose gels. Elimination of this plasmid by protoplasting and regeneration resulted in the simultaneous loss of methylenomycin A production and resistance. pSV1 hybridized with pBR322 containing a cloned fragment of 1.7 $\times 10^{6}$ daltons from $S$. coelicolor A3(2) which codes for methylenomycin A resistance. The pSV1 plasmid could be transferred to $S$. lividans by conjugation and by transformation and plasmid DNA identical in size to $\mathrm{pSVl}$ could be isolated from the recipient strains. These experiments show that pSV1 codes for methylenomycin A production and resistance, in close analogy to the SCP1 plasmid from $S$. coelicolor A3(2).
\end{abstract}

\section{INTRODUCTION}

Methylenomycin A in Streptomyces coelicolor A3(2) is the only antibiotic whose specific biosynthetic enzymes are known to be coded by genes borne on a plasmid (Hopwood, 1979). This plasmid (SCP1) was first defined genetically by Vivian (1971), who characterized strains by their recombination properties as $\mathrm{SCP}^{+}$or $\mathrm{SCP} 1^{-}$. SCP1 ${ }^{+}$strains were found to inhibit the growth of SCP1 ${ }^{-}$strains by producing a diffusible material; this was later shown (Wright \& Hopwood, 1976) to be an antibiotic identical to methylenomycin A which had previously been detected in a strain of Streptomyces violaceus-ruber (Haneishi et al., 1974a, b). The genetic evidence for the existence of SCP1 as a plasmid is substantial. SCP1 elicits lethal zygosis, a property associated with many Streptomyces plasmids (Bibb et al., 1977, 1981). Fertility states can be recognized amongst derivatives of $S$. coelicolor A3(2) with the properties expected if a sex factor were absent $\left(\mathrm{SCP}^{-}\right)$, autonomous ( $\mathrm{SCP} 1^{+}$or $\left.\mathrm{SCP} 1^{\prime}\right)$, or chromosomally integrated (Hopwood et al., 1973). The SCP1' strains (Hopwood \& Wright, 1976a), analogous to $\mathrm{F}^{\prime}$ strains of Escherichia coli, provide particularly strong evidence for SCP1 as an extrachromosomal element. $S C P 1^{\prime}$ plasmids can be transferred by mating to $S$. lividans and $S$. parvulus; the latter, at least, has little chromosomal base sequence homology with $S$. coelicolor (Westpheling, 1980).

Evidence that structural, rather than regulatory, genes for the production of methylenomycin are carried on SCP1 is of two kinds. One arises from the ability to transfer SCP1 to other species. Thus $S$. parvulus, which normally produces the totally different antibiotic actinomycin D (Williams \& Katz, 1977), makes methylenomycin A when SCP1 is mated into it (Kirby \& Hopwood, 1977). More direct evidence is provided by the isolation of point mutations (mmy) eliminating methylenomycin A production in $S$. coelicolor A3(2) strains carrying SCP1 in the integrated (NF) or autonomous states (SCP1 ${ }^{+}$or $\left.\mathrm{SCP} 1^{\prime}\right)$. All of the $m m y$ mutations isolated are linked to SCP1 rather than to the chromosome (Kirby \& Hopwood, 1977; Hornemann \& Hopwood, 1981).

Physical data on the nature of SCP1 have been difficult to obtain, since the plasmid cannot be isolated by methods which readily recover most eubacterial and some other streptomycete plasmids (Westpheling, 1980). However, physical evidence for its existence came from differen-

$\dagger$ Present address: Departamento de Microbiología, Facultad de Biología, Universidad de León, Spain. 
tial DNA hybridization experiments between $\mathrm{SCP}^{+}$and $\mathrm{SCP} 1^{-}$strains of $S$. coelicolor or between $\mathrm{SCP}^{+}{ }^{+}$strains of $S$. coelicolor and S. parvulus (Hopwood et al., 1979), together with some agarose gel electrophoresis studies (Westpheling, 1980). Okanishi et al. (1980) recently detected by electron microscopy a plasmid (pSV1) of $100 \mathrm{MDal}$ in the original methylenomycinproducing $S$. violaceus-ruber strain. The present work describes the isolation of $\mathrm{pSV} 1$ and experiments which established that this plasmid, like SCP1, determines methylenomycin synthesis and resistance. This provides a step towards a detailed physical and genetic analysis of the methylenomycin system. A preliminary report of this work has been made (Aguilar \& Hopwood, 1981).

\section{METHODS}

Bacterial strains. The bacterial strains used are listed in Table 1. Streptomyces violaceus-ruber SANK 95570 was kindly provided by Dr Y. Kishida of the Sankyo Company, Tokyo, Japan. Streptomyces lividans strain M250, carrying plasmid pSLP111, was kindly provided by Dr M. J. Bibb.

Culture conditions and transformation procedures. Luria broth (Miller, 1972) was used for the cultivation of E. coli ED8767. For antibiotic selection of $E$. coli derivatives, tetracycline was added at $10 \mu \mathrm{g} \mathrm{ml}^{-1}$ and ampicillin at $100 \mu \mathrm{g} \mathrm{ml}^{-1}$. E. coli was transformed by $\mathrm{CaCl}_{2}$ treatment (Cohen et al., 1972). Genetic techniques for Streptomyces were those of Hopwood (1967) and Hopwood et al. (1973). For the isolation of plasmid DNA from Streptomyces, strains were grown in yeast extract/malt extract medium containing $1 \mathrm{M}$-sucrose and $5 \mathrm{mM}-\mathrm{MgCl}_{2}$ (YEME) (Bibb et al., 1977). For the preparation of protoplasts, mycelium was grown in YEME medium containing $10 \mathrm{mM}-\mathrm{MgCl}_{2}$ (instead of $5 \mathrm{mM}$ ) and $66 \mathrm{~mm}$-glycine. Transformation of $S$. lividans protoplasts, using polyethylene glycol, and protoplast regeneration, were as described previously (Bibb et al., 1978) with slight modifications (Thompson et al., 1982). The source of the pSV1 DNA used in transformation was a cleared lysate prepared as described below, before agarose gel electrophoresis. Selection for $\mathrm{Mmy}^{\mathrm{r}}$ bacteria was done on complete medium (CM) agar (Hopwood, 1967) with plugs of agar containing a Mmy ${ }^{+}$strain (Hopwood \& Wright, 1976b).

DNA isolation, purification and analysis. Covalently closed circular (CCC) DNA was isolated from E. coli (Timmis et al., 1978) and S. lividans (Bibb et al., 1977) on ethidium bromide/caesium chloride density gradients. A mini-lysate procedure for analysis of plasmid DNA from $E$. coli and Streptomyces, used for screening purposes, was that of Birnboim \& Doly (1979) with slight modifications (Chater et al., 1982). pSV1 DNA was revealed in cleared lysates by the slightly modified version of Westpheling's (1980) procedure (Chater et al., 1982). For the isolation of pSV1 from gels, only part of the gel was irradiated with short-wave ultraviolet (UV) light to locate the plasmid band. The plasmid DNA from the unirradiated part was electrophoresed into filter paper backed with dialysis membrane (Girvitz et al., 1980), from which it was subsequently eluted.

Restriction endonucleases were obtained from Bethesda Research Laboratories and were used according to the manufacturer's instructions. Enzyme reactions were terminated by heating at $70^{\circ} \mathrm{C}$ for $10 \mathrm{~min}$ and were monitored for completion by agarose gel electrophoresis. This was performed with horizontal $0.7 \%(\mathrm{w} / \mathrm{v})$ agarose gels in either TBE (90 mM-Tris, $90 \mathrm{~mm}$-boric acid and $1.3 \mathrm{~mm}$-EDTA) or TAE (39 mM-Tris, $20 \mathrm{~mm}$-sodium citrate and $1 \mathrm{~mm}$-EDTA pH 8-3). After electrophoresis, the gels were stained in ethidium bromide $\left(1 \mu \mathrm{g} \mathrm{ml}^{-1}\right)$ for 20 min and the DNA bands were visualized under UV light.

Transfer to nitrocellulose and hybridization. Plasmid and chromosomal DNA bands were transferred to nitrocellulose membranes essentially as described by Wahl et al. (1979) except that the gel was first irradiated with shortwave UV light (Mineralight lamp, model UVSL-58; Ultra-violet Products Inc., San Gabriel, California) from a height of $5 \mathrm{~cm}$ for $15 \mathrm{~min}\left(2.7 \mathrm{~kJ} \mathrm{~m}^{-2}\right)$. Hybridization was performed in four times concentrated Denhardt's solution as described by Southern (1975) for 18 to $24 \mathrm{~h}$ at $65^{\circ} \mathrm{C}$. The filters were washed for $4 \mathrm{~h}$ in $2 \times \mathrm{SSC}(0 \cdot 3 \mathrm{M}-$ $\mathrm{NaCl} ; 0.03 \mathrm{M}$-sodium citrate) at $65^{\circ} \mathrm{C}$. Autoradiography was done after preflashing the film (Fuji X-ray film). The film was exposed for 1 to $14 \mathrm{~d}$ at $-70^{\circ}$ using Ilford standard intensifying screens (CAWO, West Germany).

\section{RESULTS}

\section{Antibiotic resistance and production by S. violaceus-ruber SANK 95570}

Streptomyces violaceus-ruber SANK 95570 was resistant to the methylenomycin produced in solid medium by $\mathrm{SCP} 1^{+}$strains, as well as to pure methylenomycin $\mathrm{A}$, to the same levels as $S$. coelicolor A3(2) SCP1 ${ }^{+}$strains. Thus, A3(2) and SANK 95570 were resistant to antibiotic discs containing $200 \mu \mathrm{g}$ methylenomycin whereas 1190 showed inhibition zones at $20 \mu \mathrm{g}$. SANK 95570 inhibited the growth of $\mathrm{SCP}^{-}$strains of $S$. coelicolor and, to a lesser extent, the growth of SCP1 $1^{+}$strains. The inhibition produced on $\mathrm{SCP} 1^{+}$strains was evidently due to the production of another antibiotic (or bacteriocin) different from methylenomycin. Additional evidence for the existence of this second activity came from the fact that $\mathrm{Mmy}^{-}$derivatives of SANK 95570, lacking pSV1, still produced another antibacterial activity (see below). 
Table 1. Bacterial strains

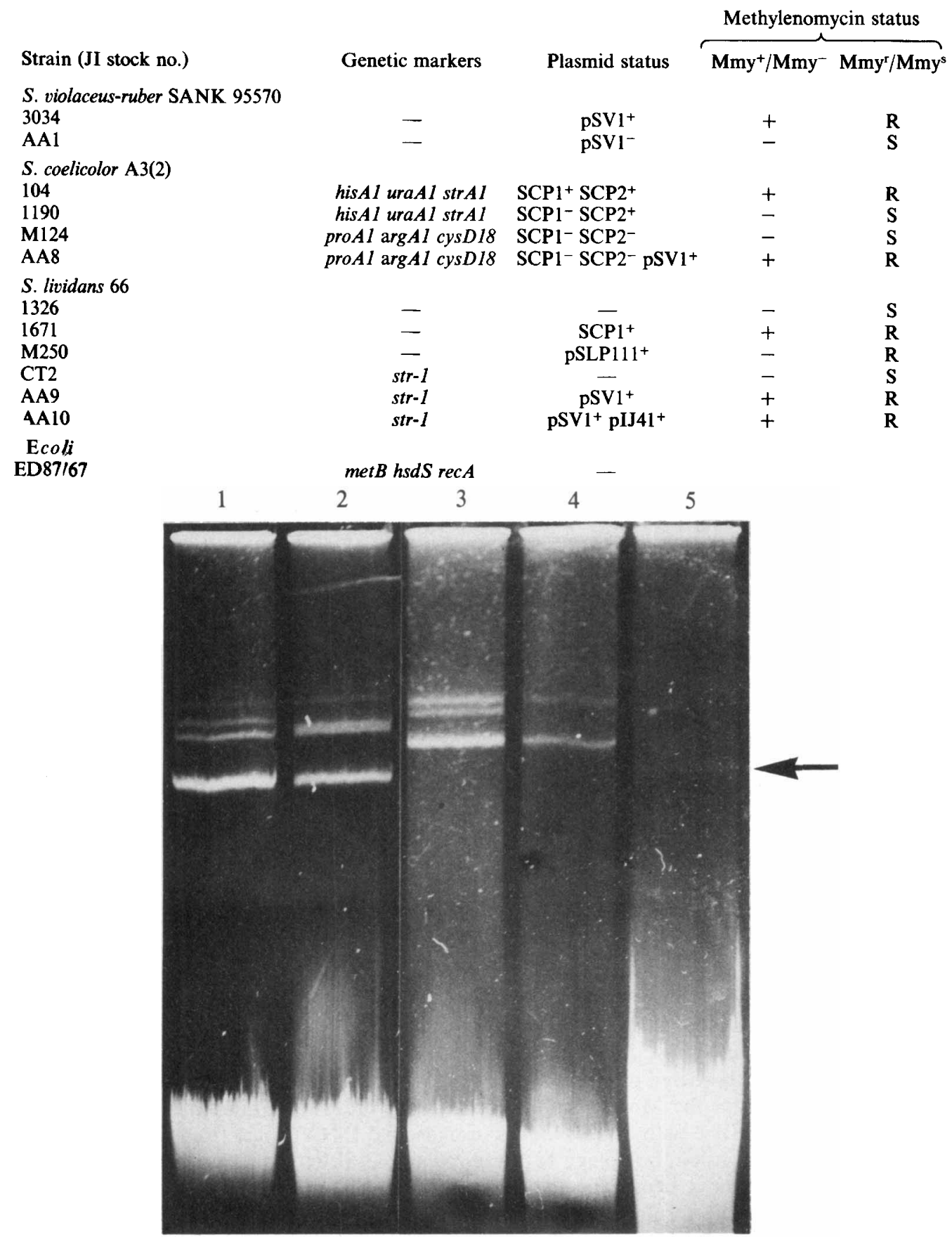

Fig. 1. Agarose gel electrophoresis of cleared lysates from Streptomyces violaceus-ruber SANK 95570 (track 5, with pSV1 arrowed) and from Rhizobium leguminosarum (tracks 1 and 2) and R. phaseoli (tracks 3 and 4). The strains (and molecular sizes of their plasmids in MDal) were as follows: Track 1, 897 (100, $165,220)$; track 2, CO15 $(100,165,195)$; track $3,148 \mathrm{~b}(130,220)$; track $4,4170(130)$. The Rhizobium plasmid preparations were kindly provided by Dr G. Hombrecher and were obtained as described by Hombrecher et al. (1981). Plasmid sizes were estimated by N. J. Brewin, A. W. B. Johnston, G. Hombrecher, N. J. Dibb, J. W. Lamb and E. A. Wood (personal communication); plasmids larger than $220 \mathrm{MDal}$ are ignored. The gel was $0.7 \%(\mathrm{w} / \mathrm{v})$ agarose, with Tris/borate buffer and was run at $4{ }^{\circ} \mathrm{C}$ for $24 \mathrm{~h}$ at $3 \cdot 3 \mathrm{~V} \mathrm{~cm}^{-1}$. 


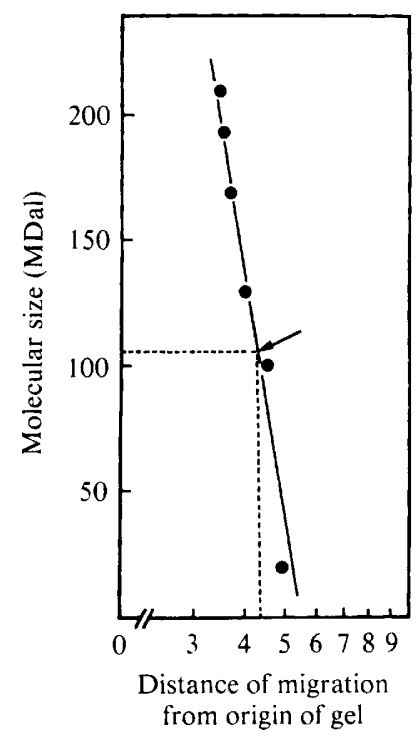

Fig. 2. Plot of relative mobility vs molecular size of different plasmids used as standards. Plasmid standards of $100,130,165,195$ and 200 MDal come from Fig. 1. The estimated molecular size of pSV1 is about $110 \mathrm{MDal}$. The mobility of SCP2 (20 MDal) was related to that of pSV1 from other gels (not shown).

\section{Detection and size of the pSV1 plasmid}

Plasmid pSV1 could be detected in cleared lysates of SANK 95570 strains using the slightly modified version of Westpheling's (1980) procedure. In Fig. 1, pSV1 is seen together with several Rhizobium plasmids. From this photograph and others (not shown), using plasmids of known molecular weight, the size of pSV1 was estimated to be about $110 \mathrm{MDal}$ (Fig. 2). The isolation method described for $\mathrm{pSV1}$ was very reproducible, although the yield of plasmid DNA was low. All attempts to purify pSV1 from $\mathrm{CsCl}$ gradients failed. pSV1 eluted from gels had usually acquired nicks but could be cleaved with restriction endonucleases, including EcoRI and BamHI.

\section{Hybridization of $p S V 1$ and $S$. coelicolor DNA to a probe containing the methylenomycin resistance gene of $S C P I$}

To determine whether pSV1 has any homology with SCP1 we prepared a probe (pIJ601) consisting of pBR322 into which a 1.1 MDal Pst I-generated DNA fragment coding for methylenomycin A resistance (Mmyr) had been inserted. The methylenomycin A fragment was originally cloned by Bibb et al. (1980) from an NF strain of $S$. coelicolor into SLP1.2 in S. lividans, replacing the region bordered by the PstI sites and giving rise to plasmid pSLP111. pBR322 was chosen as a vector for the Mmy ${ }^{\mathrm{r}}$ fragment of SCP1 in order to minimize the chance of any hybridization of SLP1.2 with Streptomyces chromosomal DNA [apart from the possibility of non-specific hybridization, homology with the integrated SLP1 sequences in the $S$. coelicolor chromosome would have been expected (Bibb et al., 1981)].

Radioactively labelled probe DNA from pIJ601 had $10^{6}$ to $10^{8}$ c.p.m. ( $\mu$ g DNA $)^{-1}$. As shown in Fig. 3, pSV1 in lysates of SANK 95570 hybridized with the probe. Hybridization was also seen with the chromosomal DNA band of SCP1 $1^{+}$strain 104, suggesting that SCP1 had been linearized during (or before) the extraction procedure. Nevertheless, in $S$. coelicolor the hybridization was specific for $\mathrm{SCP} 1^{+}$strains (data not shown). These results strongly suggest that at least methylenomycin resistance is carried by the pSV1 plasmid. They also show that, after the isolation procedure which successfully reveals pSV1 as CCC DNA, SCP1 sequences are found in the linear chromosomal DNA fraction. 


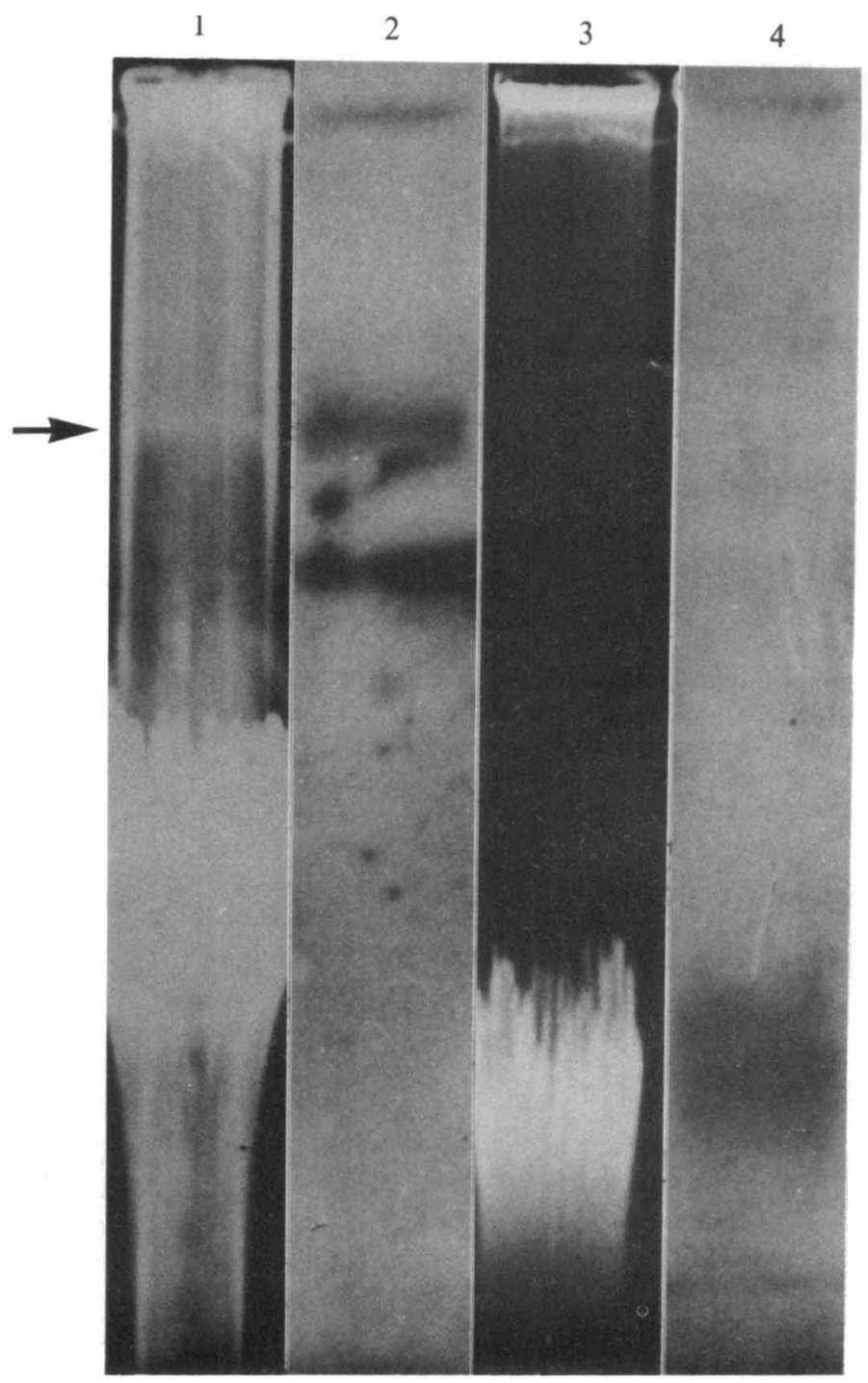

Fig. 3. Plasmid patterns (tracks 1 and 3 ) and corresponding autoradiograms, after hybridization with ${ }^{32}$ P-labelled pIJ601 probe DNA (tracks 2 and 4), of $S$. violaceus-ruber SANK 95570 (tracks 1 and 2) and $S$. coelicolor 104 (tracks 3 and 4). The DNA patterns are displayed on $0.7 \%(\mathrm{w} / \mathrm{v})$ Tris/borate agarose gels. Note hybridization of plasmid pSV1 (arrow) in track 2 . In track 4, a fraction of the chromosomal DNA shows hybridization.

Stability of the Mmy ${ }^{+}$phenotype of SANK 95570

About 1500 colonies of SANK 95570 on CM, at a density of about 100 colonies per plate, were replicated to $S$. lividans 1326 on $\mathrm{CM}$ as an indicator of $\mathrm{Mmy}$ production; no $\mathrm{Mmy}^{-}$colonies were found. The same result was obtained from an approximately equal number of colonies arising from UV-irradiated spores (about $1 \%$ survival). However, when frozen protoplasts of SANK 95570 were regenerated on R2 medium and replicated to CM seeded with $S$. lividans 66 , about $15 \%$ (11 out of 70 ) of the regenerated protoplasts were both $\mathrm{Mmy}^{-}$and $\mathrm{Mmy}^{\mathrm{s}}$ (Fig. 4). No plasmid DNA was detected in any of 10 of these isolates. 


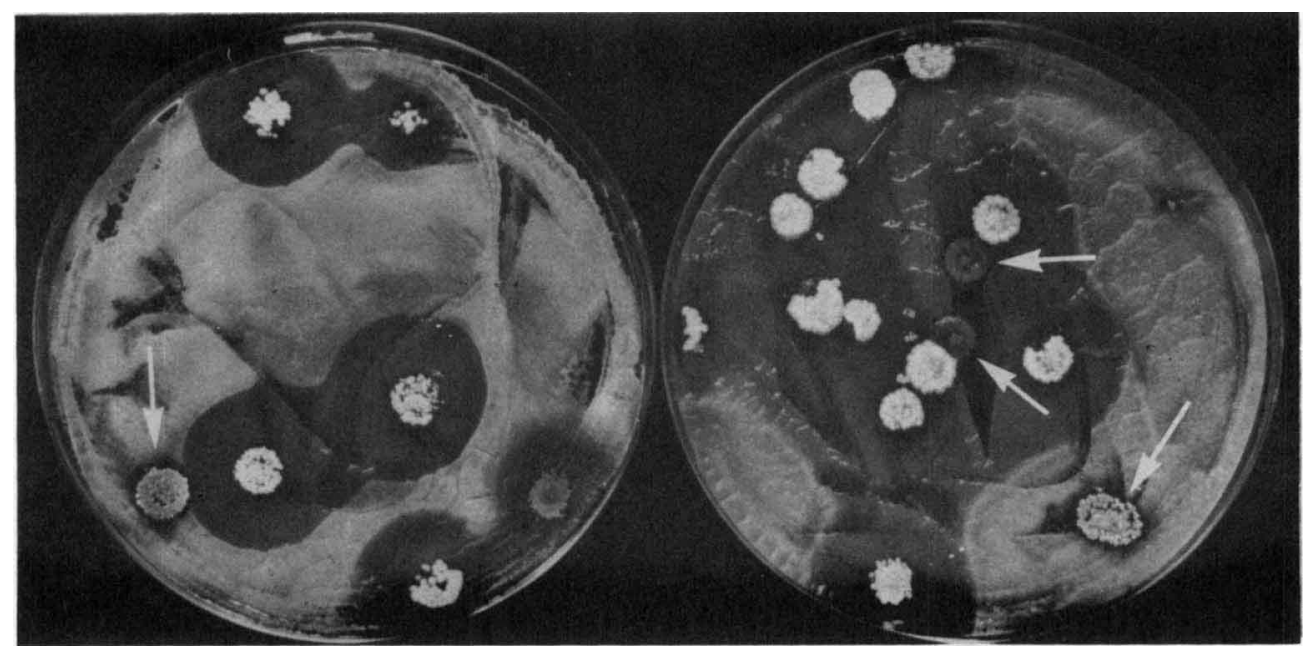

Fig. 4. Curing of methylenomycin A production (loss of pSV1) by protoplasting and regeneration of strain $S$. violaceus-ruber SANK 95570 . These cultures were produced by replica-plating two master plates containing regenerated protoplasts of SANK 95570 on to lawns of S. lividans 1326, a Mmy strain. Several Mmy- colonies can be seen (arrows).

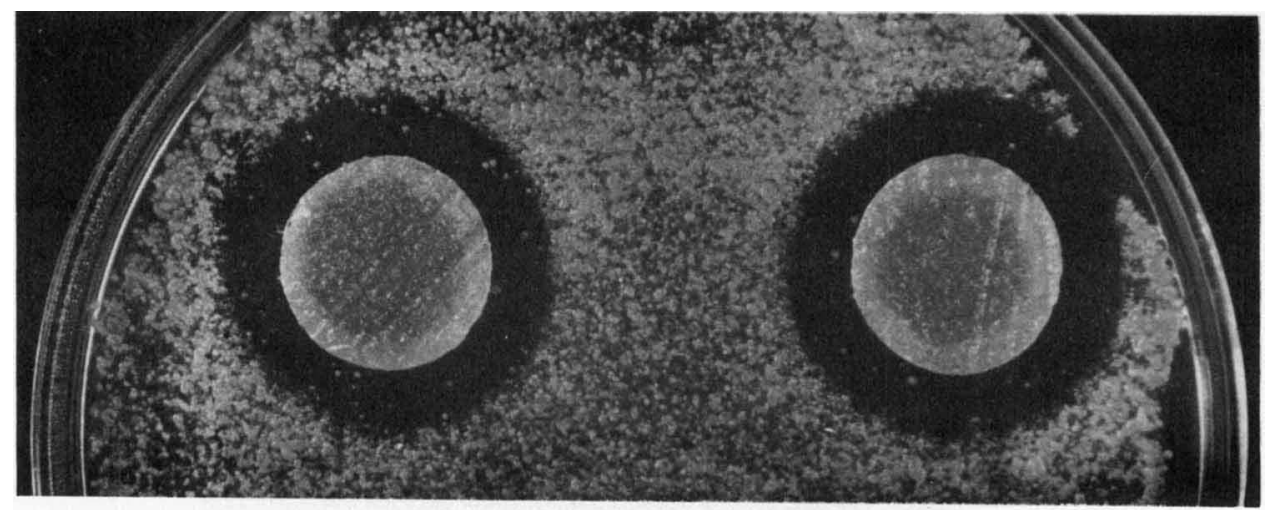

Fig. 5. Transfer of pSV1 from $S$. violaceus-ruber SANK 95570 to $S$. lividans 66. Spores from a cross between SANK $95570\left(\mathrm{Str}^{\mathrm{s}} \mathrm{pSV} 1^{+}\right)$and CT2 (S. lividans str-1) were replicated from $\mathrm{R} 2$ medium to CM medium containing $40 \mu \mathrm{g}$ streptomycin $\mathrm{ml}^{-1}$. Mmy transconjugants of $S$. lividans 66 were selected by their ability to grow in the zones of inhibition produced by plugs from a Mmy culture of SANK 95570. The Mmyr transconjugants were found to be $\mathrm{Mmy}^{+}$and to contain a plasmid identical to pSV1.

\section{Transfer of $p S V I$}

When spores from a cross of SANK 95570 and $S$. lividans CT2 (str-1) were plated on CM containing streptomycin (to counterselect the donor), $\mathrm{Mmy}^{\mathrm{r}}$ colonies of $S$. lividans were detected within the inhibition zone produced by plugs of an SCP1 ${ }^{+}$strain of Streptomyces (Fig. 5). Such $\mathrm{Mmy}^{\mathrm{r}}$ strains (e.g. AA9) were found to produce methylenomycin and to contain a plasmid of the same size as pSV1 (Fig. 6, track 4). Similarly, pSV1-containing $S$. coelicolor strains (e.g. AA8) were isolated from a mating between $S$. lividans $\mathrm{CT} 2 / \mathrm{pSV}^{+}$and $S$. coelicolor M124.

Plasmid pSV1 could also be transformed into protoplasts of $S$. lividans strain 1326. Using a cleared lysate from $S$. lividans strain AA10, carrying both pSV1 and pIJ41 (an SLP1.2 derivative carrying neomycin and thiostrepton resistances; C. J. Thompson, T. Kieser, J. M. Ward and 


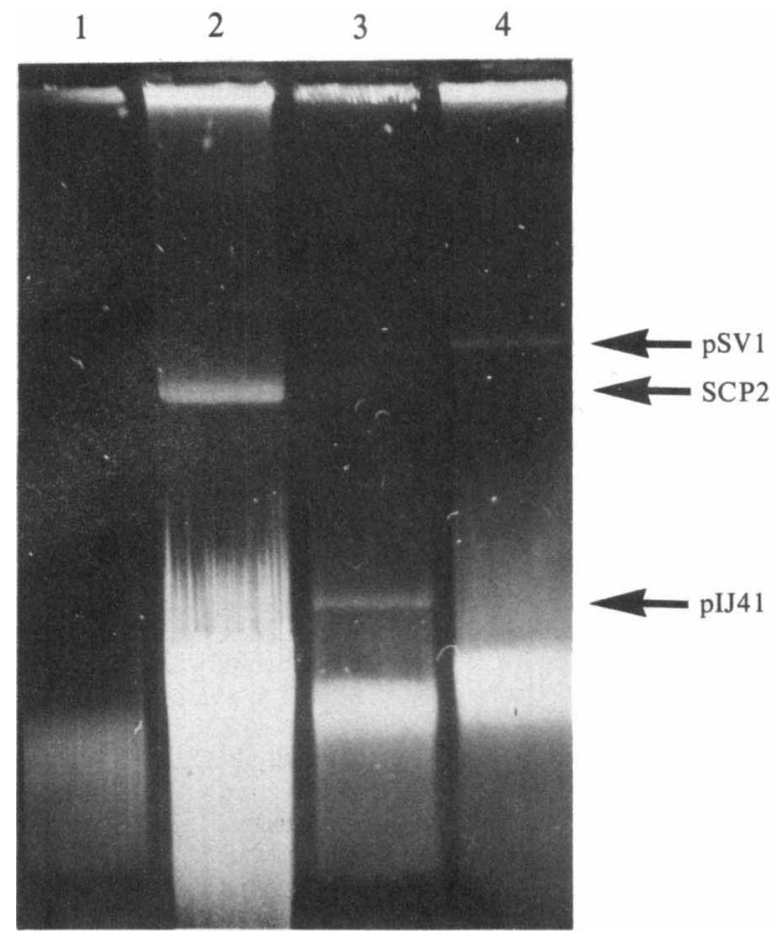

Fig. 6. Agarose gel electrophoresis of cleared lysates from different Streptomyces strains. Track 1, S. lividans $1671\left(\mathrm{SCP}^{+}\right)$; track 2, S. coelicolor $1190\left(\mathrm{SCP} 2^{+}\right)$; track 3, S. lividans AA10 (pSV1+, pIJ41 $\left.{ }^{+}\right)$; track 4, $S$. lividans AA9 (pSV1+). The gel was run for $15 \mathrm{~h}$ at $3 \mathrm{~V} \mathrm{~cm}^{-1}$.

D. A. Hopwood, unpublished results), pSV1 was transformed at a frequency $10^{3}$ times lower than pIJ41, used as an internal control. pSV1 could be successfully isolated from $\mathrm{Mmy}^{+} \mathrm{Mmy}^{\mathrm{r}}$ transformants.

\section{DISCUSSION}

The involvement of plasmids in the production of antibiotics in Streptomyces has been suggested on many occasions, and recent reviews are available (Hopwood 1978, 1979; Okanishi, 1979). In many cases the evidence for plasmid involvement is indirect and often unsatisfactory. So far, the only example in which there is strong evidence that structural genes coding for antibiotic biosynthesis are plasmid borne is provided by methylenomycin A, coded by SCP1 in S. coelicolor A3(2) (Wright \& Hopwood, 1976). Unfortunately there is little physical information on this plasmid.

The pSV1 plasmid, from a methylenomycin-producing strain of $S$. violaceus-ruber, was originally described, by electron microscopy, by Okanishi et al. (1980). We estimated its size as $110 \mathrm{MDal}$ using several plasmids as standards, in reasonable agreement with the estimate of 100 MDal made by Okanishi et al. (1980). The fact that pSV1 hybridized with a probe containing the gene (or genes) coding for methylenomycin A resistance from $S$. coelicolor suggested that this plasmid might also be responsible for methylenomycin synthesis. This was indicated by the fact that about $15 \%$ of the regenerated protoplasts from $S$. violaceus-ruber were non-producers of methylenomycin and were Mmys. In all the cases examined, there was a concomitant loss of pSVI DNA. Novick et al. (1980) and Hopwood (1981) reported that elimination of certain plasmids could be achieved during the formation and regeneration of protoplasts. The use of ethidium bromide, acriflavine and similar substances was avoided, because recent evidence (Schrempf \& Goebel, 1979; Komatsu et al., 1981) indicates that such so-called curing agents 
often provoke DNA rearrangements, including deletions and insertions, instead of physical loss of plasmids. The involvement of pSV1 in methylenomycin production was confirmed by the finding that the plasmid could be transferred, by conjugation or transformation, to $S$. lividans 66 or $S$. coelicolor A3(2), whereupon the recipient strains became resistant to methylenomycin and also produced the antibiotic.

Plasmid pSV1 resembles the SCP1 plasmid in several respects, notably methylenomycin production and resistance, large size and transmissibility. However, they differ in some unknown way which makes SCP1 very difficult to isolate (Westpheling, 1980), in spite of its apparent similarity in molecular weight to $\mathrm{pSV} 1$.

We thank Drs J. Westpheling, K. F. Chater, C. J. Thompson, T. Kieser and G. Hombrecher for valuable advice and critical comments. A.A. was recipient of a long-term EMBO fellowship.

\section{REFERENCES}

Aguilar, A. \& Hopwood, D. A. (1981). Isolation and characterization of a plasmid from Streptomyces violaceus-ruber and its relation to methylenomycin production. Society for General Microbiology Quarterly 8, 135-136.

BibB, M. J., Freeman, R. F. \& Hopwood, D. A. (1977). Physical and genetical characterization of a second sex factor, SCP2, for Streptomyces coelicolor A3(2). Molecular and General Genetics 154, 155-166.

BIBB, M. J., WARD, J. M. \& HoPWOOD, D. A. (1978). Transformation of plasmid DNA into Streptomyces at high frequency. Nature, London 274, 398-400.

Bibi, M. J., SchotTeL, J. L. \& CoHEN, S. N. (1980). A DNA cloning system for interspecies gene transfer in antibiotic-producing Streptomyces. Nature, London 284, 526-531.

BIBb, M. J., WARD, J. M., KIESER, T., COHEN, S. N. \& HOPWOOD, D. A. (1981). Excision of chromosomal DNA sequences from Streptomyces coelicolor forms a novel family of plasmids detectable in Streptomyces lividans. Molecular and General Genetics 184, 230240.

Birnboim, H. C. \& Doly, J. (1979). A rapid alkaline extraction procedure for screening recombinant plasmid DNA. Nucleic Acids Research 7, 1513-1523.

CHATER, K. F., HOPWOOD, D. A., KIESER, T. \& THOMPsON, C. J. (1982). Gene cloning in Streptomyces. Current Topics in Microbiology and Immunology 96, 6995.

Cohen, S. N., Chang, A. C. Y. \& Hsu, L. (1972). Nonchromosomal antibiotic resistance in bacteria: genetic transformation of $E$. coli by R-factor DNA. Proceedings of the National Academy of Sciences of the United States of America 69, 2110-2114.

GiRvitz, S. C., BACChETTI, S., RAINBOW, A. J. \& GRAHAM, F. L. (1980). A rapid and efficient procedure for the purification of DNA from agarose gels. Analytical Biochemistry 106, 492-496.

Haneishi, T., Kitahara, N., Takiguch, Y., Arai, M. \& Sugawara, S. (1974a). New antibiotics, methylenomycins A and B. I. Producing organism, fermentation and isolation, biological activities and physical and chemical properties. Journal of Antibiotics 27, 386-392.

Haneishi, T., Terahara, A., Arai, M., Hata, T. \& TAMURA, C. (1974b). New antibiotics, methylenomycins A and B. II. Structure of methylenomycins A and B. Journal of Antibiotics 27, 393-399.
Hombrecher, G., Brewin, N. J. \& Johnston, A. W. B.

(1981). Linkage of genes for nitrogenase and nodulation ability on plasmids in Rhizobium leguminosarum and $R$. phaseoli. Molecular and General Genetics 182 , 133-136.

HopwOod, D. A. (1967). Genetic analysis and genome structure in Streptomyces coelicolor. Bacteriological Reviews 31, 373-403.

Hopwood, D. A. (1978). Extrachromosomally determined antibiotic production. Annual Review of Microbiology 32, 373-392.

HoPwOOD, D. A. (1979). Genetics of antibiotic production by actinomycetes. Journal of Natural Products 42, 596-602.

HopwOOD, D. A. (1981). Uses of protoplasts in the genetic manipulation of streptomycetes. In Actinomycetes, pp. 523-531. Edited by K. P. Schaal \& G. Pulverer. Zentralblatt für Bakteriologie Suppl. 11. New York \& Stuttgart: Gustav Fischer.

HoPWOOD, D. A. \& WRIGHT, H. M. (1976a). Genetic studies on SCP1-prime strains of Streptomyces coelicolor A3(2). Journal of General Microbiology 95, 107120.

HOPWOOD, D. A. \& WRIGHT, H. M. (1976b). Interactions of the plasmid SCP1 with the chromosome of Streptomyces coelicolor A3(2). In Second International Symposium on the Genetics of Industrial Microorganisms, pp. 607-619. Edited by K. D. Macdonald. London: Academic Press.

Hopwood, D. A., Chater, K. F., Dowding, J. E. \& VIVIAN, A. (1973). Advances in Streptomyces coelicolor genetics. Bacteriological Reviews 37, 371-405.

HopwOOD, D. A., BibB, M. J., WARD, J. M. \& WeStPHELING, J. (1979). Plasmids in Streptomyces coelicolor and related species. In Plasmids of Medical, Environmental and Commercial Importance, pp. 245-258. Edited by K. N. Timmis \& A. Pühler. Amsterdam: Elsevier/North Holland.

HoRnemann, U. \& Hopwood, D. A. (1981). Biosynthesis of methylenomycin A, a plasmid determined antibiotic. In Antibiotics IV. Biosynthesis, pp. 123-131. Edited by J. W. Corcoran. Berlin: Springer-Verlag.

KIRBY, R. \& HoPwOOD, D. A. (1977). Genetic determination of methylenomycin synthesis by the SCP1 plasmid of Streptomyces coelicolor A3(2). Journal of General Microbiology 98, 239-252.

Komatsu, K., Leboul, J., Harford, S. \& Davies, J. 
(1981). Studies of plasmids in neomycin-producing Streptomyces. In Microbiology 1981, pp. 384-387. Edited by D. Schlessinger. Washington, D.C.: American Society for Microbiology.

MILLER, J. H. (1972). Experiments in Molecular Genetics. Cold Spring Harbor, New York: Cold Spring Harbor Laboratory.

Novick, R., SANChEz-Rivas, C., Gruss, A. \& EdelMAN, I. (1980). Involvement of the cell envelope in plasmid maintenance: plasmid curing during the regeneration of protoplasts. Plasmid 3, 348-358.

Oranishi, M. (1979). Plasmids and antibiotic synthesis in streptomycetes. In Genetics of Industrial Microorganisms, pp. 134-140. Edited by O. K. Sebek \& A. I. Laskin. Washington D.C.: American Society for Microbiology.

Okanishi, M., Manome, T. \& Umezawa, H. (1980). Isolation and characterisation of plasmid DNAs in actinomycetes. Journal of Antibiotics 33, 88-91.

SCHREMPF, H. \& GOEBEL, W. (1979). Functions of plasmid genes in Streptomyces reticuli. In Plasmids of Medical, Environmental and Commercial Importance, pp. 259-268. Edited by K. N. Timmis \& A. Pühler. Amsterdam: Elsevier/North Holland.

SOUTHERN, E. M. (1975). Detection of specific sequences among DNA fragments separated by gel electrophoresis. Journal of Molecular Biology 98, 503-517.

Thompson, C. J., Ward, J. M. \& Hopwood, D. A.
(1982). Cloning of antibiotic resistance and nutritional genes in Streptomyces. Journal of Bacteriology (in the Press).

Timmis, K. F., Cabello, F. \& Cohen, S. N. (1978). Cloning and characterization of EcoRI and HindIII restriction endonuclease-generated fragments of antibiotic resistance plasmids R6-5 and R6. Molecular and General Genetics 162, 121-137.

Vivian, A. (1971). Genetic control of fertility in Streptomyces coelicolor A3(2): plasmid involvement in the interconversion of UF and IF strains. Journal of General Microbiology 69, 353-364.

WAHL, G. M., Stern, M. \& StARK, G. R. (1979). Efficient transfer of large DNA fragments from agarose gels to diazobenzyloxymethyl-paper and rapid hybridization by using dextran sulfate. Proceedings of the National Academy of Sciences of the United States of America 76, 3683-3687.

WestPheling, J. (1980). Physical studies of Streptomyces plasmids. Ph.D. thesis, University of East Anglia, Norwich, U.K.

Williams, W. \& KaTz, E. (1977). Development of a chemically defined medium for the synthesis of actinomycin D by Streptomyces parvulus. Antimicrobial Agents and Chemotherapy 11, 281-290.

WrIGHT, L. F. \& HoPWOOD, D. A. (1976). Identification of the antibiotic determined by the SCP1 plasmid of Streptomyces coelicolor A3(2). Journal of General Microbiology 95, 96-106. 